\title{
Gambaran Elektrolit dan Gula Darah Pasien Kejang Demam yang Dirawat di Bangsal Anak RSUP Dr. M. Djamil Periode Januari 2010 - Desember 2012
}

Khairunnisa Imaduddin, Iskandar Syarif, Rahmatini

\begin{abstract}
Abstrak
Kejang demam merupakan kelainan neurologik yang paling sering dijumpai pada anak. Kejang demam merupakan bangkitan kejang yang terjadi pada saat anak demam akibat proses ekstrakranial. Kejang demam terjadi pada suhu rektal $>38 \mathrm{C}$. Penelitian ini bertujuan untuk mengetahui gambaran elektrolit dan gula darah pada pasien kejang demam yang dirawat di bangsal anak RSUP Dr. M. Djamil. Penelitian ini merupakan penelitian deskriptif menggunakan metode retrospektif dengan mengambil data dari bagian rekam medis RSUP Dr. M.Djamil. Sampel penelitian adalah seluruh pasien kejang demam yang dirawat di bangsal anak RSUP Dr. M. Djamil periode Januari 2010 - Desember 2012 yang memenuhi kriteria inklusi. Dari 173 kasus kejang demam, terdapat 51 kasus yang memenuhi kriteria sampel penelitian. Sebagian besar sampel merupakan kejang demam pertama (76,5\%). Kejang demam kompleks didapatkan sebesar $64,7 \%$. Kasus kejang demam terbanyak terjadi pada kelompok usia $\geq 6$ bulan $<$ 2 tahun yaitu sebesar 51\%. Kejang demam lebih sering terjadi pada laki-laki daripada perempuan dengan perbandingan 1,4:1. Penelitian menunjukkan penurunan nilai natrium serum ( $n=46,80,4 \%)$, dan kalsium serum ( $n=30$, $63,3 \%$ ), nilai kalium serum normal $(n=46,76,1 \%)$, dan peningkatan nilai gula darah sewaktu $(n=45,57,8 \%)$. Pada pasien kejang demam ditemukan penurunan nilai natrium dan kalsium serum, nilai kalium serum normal, dan peningkatan nilai gula darah sewaktu. Diharapkan penelitian yang akan datang memiliki jumlah sampel yang lebih besar untuk mengetahui gambaran elektrolit dan gula darah pada pasien kejang demam.
\end{abstract}

Kata kunci: kejang demam, natrium serum, kalium serum, kalsium serum, gula darah sewaktu

\begin{abstract}
Febrile seizure is the most common neurological disorder found in children. Febrile seizure is seizure that occurs while the children have fever caused by extracranial process. It occurs in rectal temperature $>38 \mathrm{C}$. This research aim to describe the electrolytes and blood glucose in patients with febrile seizure who were treated at the pediatric's ward of Dr. M. Djamil general hospital. From 173 cases of febrile seizures, there are 51 cases that meet the criterias of the research sample. Most of the research samples are first febrile seizure (76.5\%). Complex febrile seizure occurred in $64.7 \%$. Most cases of febrile seizures occurred in the age group $\geq 6$ months $-<2$ years, about $51 \%$. Febrile seizures are more common in males than females with the ratio 1.4:1. The research shows decrease serum sodium ( $n=46,80.4 \%)$, and serum calcium ( $n=30,63.3 \%)$, normal serum potassium $(n=46,76.1 \%)$, and increase non-fasting blood glucose level ( $n=45,57.8 \%)$. The patients with febrile seizure show decrease serum sodium and calcium, normal serum potassium, and increase non-fasting blood glucose level. Expected future studies have a lot of samples in determining the electrolytes and blood glucose in patients with febrile seizure.
\end{abstract}

Keywords: febrile seizures, serum sodium, serum potassium, serum calcium, non-fasting blood glucose level

Affiliasi penulis : Khairunnisa Imaduddin,

Korespondensi : Fakultas Kedokteran Universitas Andalas, email : Khairunnisa Imaduddin, Telp: 08561319153

\section{Pendahuluan}

Kejang demam merupakan kelainan neurologis yang paling sering terjadi pada anak. Kejang demam adalah bangkitan kejang yang terjadi pada suhu rektal $>38^{\circ} \mathrm{C}$ yang disebabkan oleh suatu proses ekstrakranial. Sekitar $2-5 \%$ anak dibawah lima tahun pernah mengalami kejang demam.

Dalam menegakkan suatu diagnosis, kadang dibutuhkan suatu pemeriksaan penunjang. Salah satu pemeriksaan penunjang pada kasus kejang demam adalah pemeriksaan laboratorium darah dan elektrolit yang digunakan untuk mengetahui penyebab terjadinya bangkitan kejang demam, mencari sumber infeksi penyebab demam, dan memperkirakan perjalanan penyakit atau prognosis penderita kejang demam $^{2}$

American Academy of Pediatrics merekomendasikan pemeriksaan elektrolit serum rutin, gula darah, kalsium, fosfor, magnesium, dan hitung darah lengkap pada anak dengan kejang demam usia enam bulan dan lebih yang tidak terdapat pemeriksaan fisik abnormal dan gejala lain yang mencurigakan, misalnya muntah dan diare. ${ }^{3}$

\section{Metode}

Penelitian ini merupakan penelitian deskriptif dengan metode retrospektif. Penelitian ini dilakukan di bagian rekam medik RSUP Dr. M. Djamil Padang yang berlangsung dari bulan Juni 2012 sampai Maret 2013. Populasi pada penelitian ini adalah seluruh penderita kejang demam yang dirawat di bangsal anak RSUP Dr. M. Djamil periode Januari 2010 - Desember 2012. Sampel yang digunakan merupakan seluruh populasi rekam medik yang memenuhi kriteria inklusi dan eksklusi yaitu sebanyak 51 sampel. Kriteria eksklusi dari penelitian ini adalah data rekam medis yang tidak lengkap dan pasien kejang demam dengan penyakit penyerta lain yang dapat mengakibatkan perubahan elektrolit dan gula darah, yaitu diare akut dengan dehidrasi. 
Variabel pada penelitian ini adalah kejang demam, jenis kejang demam, episode kejang, usia, jenis kelamin, natrium, kalium, dan kalsium serum serta gula darah sewaktu. Kejang demam sederhana adalah kejang demam yang bersifat umum, berlangsung $<15$ menit, dan tidak berulang dalam 24 jam. Kejang demam kompleks merupakan bangkitan kejang demam yang bersifat fokal atau kejang umum yang didahului kejang parsial, berlangsung $>15$ menit, dan berulang dalam 24 jam. Kejang demam plus terjadi pada anak yang berusia $>5$ tahun. Episode kejang pertama menunjukkan tidak pernah mengalami kejang dengan atau tanpa demam sebelumnya, sedangkan kejang ulangan berarti anak pernah mengalami kejang demam sebelumnya.

Pengolahan data dilakukan secara manual. Analisis data merupakan analisis univariat.

Hasil

Dari 51 jumlah sampel, tidak seluruh sampel penelitian menjalani pemeriksaan laboratorium. Sebanyak 46 sampel menjalani pemeriksaan natrium, 46 sampel menjalani pemeriksaan kalium, dan 30 sampel menjalani pemeriksaan kalsium serum, serta 45 sampel menjalani pemeriksaan gula darah sewaktu.

Gambar 1. Distribusi Kejang Demam Berdasarkan Jenis Kejang Demam

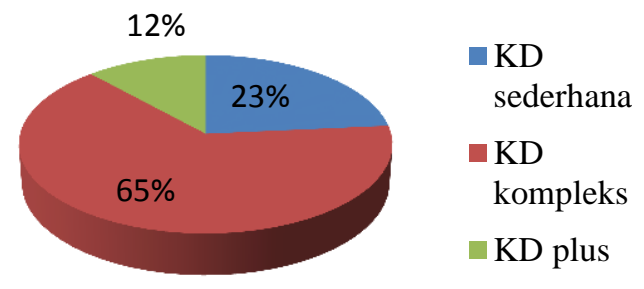

Gambar 1 menunjukkan sebagian besar pasien kejang demam yang dirawat mengalami kejang demam kompleks, yaitu sebanyak 33 kasus (65\%), dengan 21 kasus kejang berlangsung $>15$ menit, 12 kasus bangkitan kejang berulang dalam 24 jam, dan tidak ada kasus kejang yang bersifat fokal. Kejang demam plus, yaitu kejang demam yang terjadi pada anak dengan usia lebih dari lima tahun terdapat sebanyak 6 kasus (12\%).

Gambar 2. Distribusi Kejang Demam Berdasarkan Episode Kejang

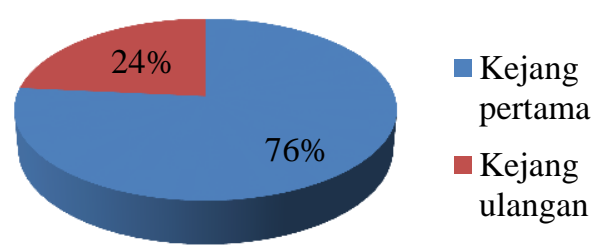

Gambar 2 menunjukkan sebagian besar pasien kejang demam mengalami episode kejang pertama, yaitu sebanyak 39 kasus (76\%).
Perbandingan kejadian episode kejang pertama dan ulangan adalah $3,3: 1$.

Tabel 1. Distribusi Frekuensi Kejang Demam Berdasarkan Usia

\begin{tabular}{|c|c|c|c|c|c|c|}
\hline \multirow[t]{2}{*}{ Usia } & \multicolumn{2}{|c|}{$\begin{array}{c}\text { Kejang } \\
\text { Pertama }\end{array}$} & \multicolumn{2}{|c|}{$\begin{array}{c}\text { Kejang } \\
\text { Ulangan }\end{array}$} & \multicolumn{2}{|c|}{ Jumlah } \\
\hline & $\mathbf{n}$ & $\%$ & $\mathbf{n}$ & $\%$ & $\mathbf{N}$ & $\%$ \\
\hline $\begin{array}{l}\geq 1 \text { bulan }- \\
<6 \text { bulan }\end{array}$ & 3 & 5,9 & 0 & 0 & 3 & 5,9 \\
\hline $\begin{array}{l}\geq 6 \text { bulan }- \\
<1 \text { tahun }\end{array}$ & 12 & 23,5 & 1 & 2,0 & 13 & 25,5 \\
\hline $\begin{array}{l}\geq 1 \text { tahun }- \\
<2 \text { tahun }\end{array}$ & 9 & 17,6 & 4 & 7,8 & 13 & 25,4 \\
\hline $\begin{array}{l}\geq 2 \text { tahun }- \\
<3 \text { tahun }\end{array}$ & 8 & 15,7 & 3 & 5,9 & 11 & 21,6 \\
\hline $\begin{array}{l}\geq 3 \text { tahun }- \\
<4 \text { tahun }\end{array}$ & 3 & 5,9 & 1 & 2,0 & 4 & 7,9 \\
\hline $\begin{array}{l}\geq 4 \text { tahun }- \\
<5 \text { tahun }\end{array}$ & 0 & 0 & 0 & 0 & 0 & 0 \\
\hline $\begin{array}{c}\geq 5 \text { tahun }- \\
<6 \text { tahun }\end{array}$ & 0 & 0 & 1 & 2,0 & 1 & 2,0 \\
\hline$\geq 6$ tahun & 4 & 7,8 & 2 & 3,9 & 6 & 11,7 \\
\hline Jumlah & 39 & 76,4 & 12 & 23,6 & 51 & 100 \\
\hline
\end{tabular}

Tabel 1 menunjukkan penderita kejang demam terbanyak pada usia $\geq 6$ bulan $-<2$ tahun yaitu sebanyak 26 kasus $(51 \%)$. Tidak terdapat kasus kejang demam pada kelompok usia usia $\geq 4$ tahun $-<5$ tahun. Terdapat kasus kejang demam dengan usia terkecil 3 bulan dan usia terbesar 11 tahun, masingmasing sebanyak dua kasus.

Tabel 2. Distribusi Frekuensi Kejang Demam Berdasarkan Jenis Kelamin

\begin{tabular}{ccccccc}
\hline \multirow{2}{*}{$\begin{array}{c}\text { Jenis } \\
\text { Kelamin }\end{array}$} & \multicolumn{2}{c}{$\begin{array}{c}\text { Kejang } \\
\text { Pertama }\end{array}$} & \multicolumn{2}{c}{$\begin{array}{c}\text { Kejang } \\
\text { Ulangan }\end{array}$} & \multicolumn{2}{c}{ Jumlah } \\
\cline { 2 - 7 } & $\mathbf{n}$ & $\%$ & $\mathbf{n}$ & $\%$ & $\mathbf{N}$ & $\%$ \\
\hline Laki-laki & 21 & 41,2 & 9 & 17,6 & 30 & 58,8 \\
Perempuan & 18 & 35,3 & 3 & 5,9 & 21 & 41,2 \\
\hline Jumlah & $\mathbf{3 9}$ & $\mathbf{7 6 , 5}$ & $\mathbf{1 2}$ & $\mathbf{2 3 , 5}$ & $\mathbf{5 1}$ & $\mathbf{1 0 0}$ \\
\hline
\end{tabular}

Pada tabel 2 dapat dilihat kasus kejang demam lebih banyak terjadi pada laki-laki yaitu sebanyak 30 kasus (58.8\%). Perbandingan kejadian kejang demam pada laki-laki dan perempuan sebesar $1,4: 1$. Kasus terbanyak episode kejang pertama dan kejang ulangan terjadi pada laki-laki, masing-masing sebanyak 21 kasus $(41,2 \%)$ dan 9 kasus $(17,6 \%)$.

Tabel 3. Distribusi Frekuensi Kejang Demam Berdasarkan Hasil Pemeriksaan Natrium Serum

\begin{tabular}{lcccccc}
\hline \multirow{2}{*}{$\begin{array}{c}\text { Natrium } \\
\text { Serum }\end{array}$} & \multicolumn{2}{c}{$\begin{array}{c}\text { Kejang } \\
\text { Pertama }\end{array}$} & \multicolumn{2}{c}{$\begin{array}{c}\text { Kejang } \\
\text { Ulangan }\end{array}$} & \multicolumn{2}{c}{ Jumlah } \\
\cline { 2 - 7 } & $\mathbf{n}$ & $\%$ & $\mathbf{n}$ & $\%$ & $\mathbf{N}$ & $\%$ \\
\hline Hipo- & 28 & 60,8 & 9 & 19,6 & 37 & 80,4 \\
natremia & 7 & 15,2 & 2 & 4,4 & 9 & 19,6 \\
Normal & 0 & 0 & 0 & 0 & 0 & 0 \\
$\begin{array}{l}\text { Hiper- } \\
\text { natremia }\end{array}$ & $\mathbf{3 5}$ & $\mathbf{7 6}$ & $\mathbf{1 1}$ & $\mathbf{2 4}$ & $\mathbf{4 6}$ & $\mathbf{1 0 0}$ \\
\hline \multicolumn{1}{c}{ Jumlah } & $\mathbf{3 5}$
\end{tabular}

Tabel 3 menunjukkan sebagian besar pasien mengalami hiponatremia dengan nilai natrium serum $<138 \mathrm{mEq} / \mathrm{L}$ yaitu sebanyak 37 kasus $(80,4 \%)$. Tidak ditemukan kasus hipernatremia dengan nilai natrium serum $>145 \mathrm{mEq} / \mathrm{L}$. 
Tabel 4. Distribusi Frekuensi Kejang Demam Berdasarkan Hasil Pemeriksaan Kalium Serum

\begin{tabular}{|c|c|c|c|c|c|c|}
\hline \multirow{2}{*}{$\begin{array}{c}\text { Kalium } \\
\text { Serum }\end{array}$} & \multicolumn{2}{|c|}{$\begin{array}{c}\text { Kejang } \\
\text { Pertama }\end{array}$} & \multicolumn{2}{|c|}{$\begin{array}{l}\text { Kejang } \\
\text { Ulangan }\end{array}$} & \multicolumn{2}{|c|}{ Jumlah } \\
\hline & $n$ & $\%$ & $\mathrm{n}$ & $\%$ & $\mathrm{n}$ & $\%$ \\
\hline $\begin{array}{l}\text { Hipo- } \\
\text { kalemia }\end{array}$ & 6 & 13,0 & 1 & 2,2 & 7 & 15,2 \\
\hline Normal & 25 & 54,4 & 10 & 21,7 & 35 & 76,1 \\
\hline $\begin{array}{l}\text { Hiper- } \\
\text { kalemia }\end{array}$ & 4 & 8,7 & 0 & 0 & 4 & 8,7 \\
\hline Jumlah & 35 & 76,1 & 11 & 23,9 & 46 & 100 \\
\hline
\end{tabular}

Tabel 4 menunjukkan sebagian besar kasus $(76,1 \%)$ memiliki nilai kalium serum yang normal yaitu 3,5-5,0 mEq/L. Hipokalemia didapatkan pada 7 kasus $(15,2 \%)$ dan hiperkalemia pada 4 kasus $(8,7 \%)$.

Tabel 5. Distribusi Frekuensi Kejang Demam Berdasarkan Hasil Pemeriksaan Kalsium Serum

\begin{tabular}{|c|c|c|c|c|c|c|}
\hline \multirow{2}{*}{$\begin{array}{c}\text { Kalsium } \\
\text { Serum }\end{array}$} & \multicolumn{2}{|c|}{$\begin{array}{l}\text { Kejang } \\
\text { Pertama }\end{array}$} & \multicolumn{2}{|c|}{$\begin{array}{c}\text { Kejang } \\
\text { Ulangan }\end{array}$} & \multicolumn{2}{|c|}{ Jumlah } \\
\hline & $f$ & $\%$ & $f$ & $\%$ & $f$ & $\%$ \\
\hline $\begin{array}{l}\text { Hipo- } \\
\text { kalsemia }\end{array}$ & 13 & 43,4 & 6 & 20 & 19 & 63,3 \\
\hline Normal & 10 & 33,4 & 1 & 3,3 & 11 & 36,7 \\
\hline $\begin{array}{l}\text { Hiper- } \\
\text { kalsemia }\end{array}$ & 0 & 0 & 0 & 0 & 0 & 0 \\
\hline Jumlah & 23 & 76,7 & 7 & 23,3 & 30 & 100 \\
\hline
\end{tabular}

Tabel 5 menunjukkan pada sebagian besar kasus kejang demam terjadi hipokalsemia dengan nila kalsium serum $<8,8 \mathrm{mEq} / \mathrm{L}$, yaitu sebanyak 19 kasus $(63,3 \%)$. Tidak terdapat kasus kejang demam yang disertai dengan hiperkalsemia (kalsium serum > 10,8 $\mathrm{mEq} / \mathrm{L})$.

Tabel 6. Distribusi Frekuensi Kejang Demam Berdasarkan Hasil Pemeriksaan Gula Darah Sewaktu

\begin{tabular}{|c|c|c|c|c|c|c|}
\hline \multirow{2}{*}{$\begin{array}{c}\text { Gula Darah } \\
\text { Sewaktu }\end{array}$} & \multicolumn{2}{|c|}{$\begin{array}{c}\text { Kejang } \\
\text { Pertama }\end{array}$} & \multicolumn{2}{|c|}{$\begin{array}{l}\text { Kejang } \\
\text { Ulangan }\end{array}$} & \multicolumn{2}{|c|}{ Jumlah } \\
\hline & $f$ & $\%$ & $f$ & $\%$ & $f$ & $\%$ \\
\hline \multirow{3}{*}{$\begin{array}{l}\text { Hipo- } \\
\text { glikemia } \\
\text { Normal } \\
\text { Hiper- } \\
\text { glikemia }\end{array}$} & 0 & 0 & 0 & 0 & 0 & 0 \\
\hline & 17 & 37,8 & 2 & 4,4 & 19 & 42,2 \\
\hline & 18 & 40 & 8 & 17,8 & 26 & 57,8 \\
\hline Jumlah & 35 & 77,8 & 10 & 22,2 & 45 & 100 \\
\hline
\end{tabular}

Pada tabel 6 dapat dilihat sebagian besar nilai gula darah sewaktu pada kasus kejang demam mengalami peningkatan yaitu sebanyak 26 kasus $(57,8 \%)$. Nilai gula darah sewaktu normal $(60-100$ $\mathrm{mg} / \mathrm{dl}$ ) sebesar $42,2 \%$. Tidak terdapat kasus dengan hipoglikemia.

\section{Pembahasan}

Kasus kejang demam yang dirawat di bangsal anak RSUP Dr. M. Djamil Padang pada periode Januari 2010 - Desember 2012 adalah 173 dan terdapat 51 kasus yang memenuhi kriteria sampel penelitian. Sebagian besar kasus merupakan kejang demam kompleks, yaitu sebanyak 33 kasus $(64,7 \%)$, dengan 21 kasus kejang berlangsung $>15$ menit, 12 kasus bangkitan kejang berulang dalam 24 jam, dan tidak ada kasus kejang yang bersifat fokal. Kasus kejang demam sederhana hanya sebanyak 12 kasus $(23,5 \%)$. Kasus kejang demam plus yang terjadi pada anak $>5$ tahun sebanyak 6 kasus $(11,8 \%)$. Menurut Friedman, $80 \%$ kasus kejang demam yang terjadi merupakan kejang demam sederhana, hanya sekitar $20 \%$ kasus yang merupakan kejang demam kompleks ${ }^{1}$. Pada penelitian ditemukan lebih banyak kejang demam kompleks karena penentuan kasus tersebut kejang demam sederhana atau kompleks didapatkan dari anamnesis keluarga pasien berupa sifat kejang (umum atau fokal), lamanya kejang, dan frekuensi kejang (berulang dalam 24 jam atau tidak). Penilaian tersebut bersifat subjektif. Keluarga pasien mungkin tidak tahu pasti berapa lama kejang terjadi karena saat terjadi kejang keluarga tidak terlalu memperhatikan waktu karena lebih mengutamakan kesehatan dan keselamatan anak serta bagaimana cara menghentikan kejang. Kejang yang berlangsung $<15$ menit dianggap >15 menit karena keluarga menganggap kejang tersebut berlangsung terlalu lama padahal keluarga tidak memperhatikan jam, terutama pada keluarga atau orang tua yang baru pertama kali menghadapi kejang demam. Tidak semua kasus kejang demam perlu dirawat inap, terutama kejang yang hanya terjadi sekali atau berlangsung sebentar Selain itu, bangkitan kejang yang hanya terjadi sekali atau sebentar mungkin tidak terlalu mengkhawatirkan bagi orang tua sehingga orang tua menolak anaknya untuk dirawat.

Dari 51 kasus yang digunakan sebagai sampel penelitian, 39 kasus $(76,5 \%)$ merupakan episode kejang pertama dan 12 kasus (23,5\%) merupakan episode kejang ulangan. Perbandingan kejadian episode kejang pertama dan ulangan adalah 3,3:1. Kejang pertama terbanyak terjadi pada laki-laki dan kelompok usia $\geq 6$ bulan $-<1$ tahun. Kejang ulangan terbanyak terjadi pada laki-laki dan kelompok usia $\geq 1$ tahun $-<2$ tahun. Menurut Lewis $P$. Rowland dan Timothy $A$. Pedley sepertiga dari anak dengan kejang demam mendapatkan lebih dari satu kali serangan kejang demam. ${ }^{4}$ Sekitar $75 \%$ kejang demam berulang dalam satu tahun. Usia kejang demam pertama <18 bulan, genetik, dan durasi demam yang singkat sebelum terjadinya kejang merupakan faktorfaktor yang mempengaruhi berulangnya kejang demam. ${ }^{5}$ Pada penelitian ini tidak dapat dinilai faktorfaktor yang dapat mempengaruhi berulangnya kejang demam karena data yang tidak lengkap mengenai usia pertama kali anak mengalami kejang demam. Durasi demam sebelum terjadinya bangkitan kejang yang didapatkan dari anamnesis terhadap keluarga pasien mungkin tidak sepenuhnya dapat dipercaya. Informasi tersebut bersifat objektif dan mungkin keluarga atau orang tua pasien terlambat menyadari peningkatan suhu tubuh yng terjadi pada anak sehingga informasi yang didapat kurang akurat.

Kasus kejang demam paling banyak terjadi pada kelompok usia $\geq 6$ bulan $-<1$ tahun dan $\geq 1$ tahun - <2 tahun yaitu masing-masing sebanyak 13 kasus (25,5\%). Hasil ini sesuai dengan penelitian terdahulu di RSUP Dr. M. Djamil pada tahun 2005-2006 yang didapatkan kasus kejang demam terbanyak terjadi pada kelompok usia 1-2 tahun. ${ }^{6}$ Menurut Consensus Statement on Febrile Seizures kejang demam biasanya terjadi antara usia 3 bulan dan 5 tahun $^{5}$. Dari penelitian yang dilakukan didapatkan sebanyak 41 kasus $(80,4 \%)$ penderita kejang demam berusia $\geq 6$ bulan - $<5$ tahun. Pada penelitian didapatkan didapatkan kejang demam yang terjadi pada usia di atas 5 tahun sebanyak 6 kasus $(11,8 \%)$. Pada anak masih terjadi fase perkembangan otak. Pada fase ini regulasi ion belum sempurna sehingga dapat terjadi gangguan repolarisasi dan peningkatan eksitabilitas 
sel saraf. Selain itu pada fase ini mekanisme eksitasi lebih dominan daripada inhibisi. Hal tersebut terjadi karena reseptor eksitasi aktif sedangkan reseptor inhibisi kurang aktif. ${ }^{7}$

Kasus kejang demam pada laki-laki sebanyak 30 kasus $(58,8 \%)$. Kasus kejang demam pada perempuan lebih sedikit, yaitu 21 kasus $(41,2 \%)$. Perbandingan kasus kejang demam pada laki-laki dan perempuan didapatkan sebesar 1,4:1. Millar juga mendapatkan perbandingan yang sama antara kasus kejang demam pada laki-laki dan perempuan, yaitu sebesar $1,4: 1^{8}$

Berdasarkan penelitian yang dilakukan, sebagian besar kasus kejang demam disertai dengan keadaan hiponatremia, yaitu sebanyak 37 kasus $(80,4 \%)$ dan tidak didapatkan kasus dengan hipernatremia. Tidak terdapat perbedaan nilai natrium serum yang bermakna pada kasus kejang pertama dan kejang ulangan. Pada penelitian yang dilakukan oleh Nickavar didapatkan nilai natrium serum rata-rata anak yang menderita kejang demam lebih rendah daripada anak yang tidak mengalami kejang demam namun tidak terdapat perbedaan nilai natrium serum yang berarti antara kejang demam pertama dan berulang ${ }^{9}$. Penelitian yang dilakukan oleh Zeng-quan juga menunjukkan penurunan nilai natrium yang bermakna pada penderita kejang demam dibandingkan kelompok yang tidak mengalami kejang demam $^{10}$. Hal tersebut dapat disebabkan oleh terjadinya mutasi pada gen yang mengatur kanal natrium. Mutasi tersebut mengakibatkan proses aktif pintu kanal ion natrium berkepanjangan. Aktivasi pintu kanal ion natrium mengakibatkan masuknya natrium ke dalam sel sehingga terjadi depolarisasi. Pembukaan pintu kanal ion natrium yang berkepanjangan dapat meningkatkan eksitabilitas membran sel neuron. ${ }^{2,11}$

Sebagian besar kasus kejang demam yang diteliti $(76,1 \%)$ memiliki nilai kalium serum yang normal. Hanya 7 kasus (15,2\%) yang disertai dengan penurunan nilai kalium serum dan 4 kasus $(8,7 \%)$ yang disertai dengan peningkatan nilai kalium serum. Tidak terdapat perbedaan nilai kalium serum yang bermakna pada kasus kejang pertama dan kejang ulangan. Hasil ini sesuai dengan penelitian yang dilakukan oleh Akbayram yang menemukan nilai kalium pada penderita kejang demam lebih rendah dibandingkan dengan kelompok kontrol. ${ }^{12}$ Penelitian yang dilakukan oleh Zeng-quan tidak terdapat perbedaan nilai kalium serum yang bermakna antara kelompok kejang demam dan kelompok anak yang hanya mengalami demam ${ }^{10}$. Terbukanya pintu kanal ion kalium mengakibatkan hiperpolarisasi. Keadaan tersebut merupakan suatu mekanisme inhibisi yang dapat menghambat potensial aksi. ${ }^{2}$ Pembukaan kanal ion kalium mengakibatkan kalium keluar sel sehingga konsentrasi kalium di luar sel akan meningkat. Penurunan nilai kalium serum dapat mengurangi mekanisme inhibisi. Mekanisme inhibisi yang tidak sebanding dengan mekanisme eksitasi dapat mencetuskan terjadinya bangkitan kejang.

Nilai kalsium serum mengalami penurunan pada sebagian besar kasus kejang demam, yaitu sebanyak 19 kasus (63,3\%). Nilai kalsium normal ditemukan pada 11 kasus (36,7\%). Tidak ditemukan kasus dengan peningkatan nilai kalsium serum. Tidak terdapat perbedaan nilai kalsium serum yang bermakna pada kasus kejang pertama dan kejang ulangan. Pada penelitian yang dilakukan oleh
Akbayram didapatkan nilai kalsium serum penderita kejang demam lebih rendah dibandingkan dengan kelompok kontrol. ${ }^{12}$ Penelitian yang dilakukan oleh Zeng-quan tidak terdapat perbedaan nilai kalsium serum yang bermakna antara kelompok kejang demam dan kelompok anak yang hanya mengalami demam. ${ }^{10}$ Menurut Nickavar nilai kalsium serum penderita kejang demam juga lebih rendah dibandingkan dengan kelompok yang tidak menderita kejang demam namun tidak ditemukan perbedaan nilai kalsium serum yang berarti pada kelompok kejang demam pertama dan berulang. ${ }^{9}$ Ion kalsium berperan dalam terjadinya depolarisasi. Konsentrasi kalsium serum yang mengalami penurunan dapat mengurangi jumlah depolarisasi yang diperlukan untuk memicu perubahan konduktansi natrium dan kalium. Hal ini dapat mengakibatkan peningkatan eksitabilitas sel saraf dan sel otot yang dapat memicu terjadinya bangkitan kejang. ${ }^{11}$

Dari penelitian yang telah dilakukan, didapatkan peningkatan nilai gula darah sewaktu pada sebagian besar penderita kejang demam, yaitu sebanyak 26 kasus $(57,8 \%)$. Nilai gula darah normal ditemukan pada 19 kasus (42,2\%) dan tidak ada kasus dengan hipoglikemia. Tidak terdapat perbedaan nilai gula darah sewaktu yang bermakna pada kasus kejang pertama dan kejang ulangan. Penelitian Zengquan juga menunjukkan nilai glukosa darah pada pasien kejang demam lebih tinggi dibandingkan dengan pasien yang tidak atau mengalami demam. ${ }^{10}$ Peningkatan nilai gula darah dapat terjadi pada suatu proses penyakit akut disebut juga stress hiperglikemia. Keadaan ini terjadi karena adanya interaksi antara katekolamin, hormon pertumbuhan, kortisol, dan sitokin. Interaksi tersebut mengakibatkan terjadinya peningkatan produksi glukosa hepar (terutama glukoneogenesis) dan resistensi insulin. Resistensi insulin yang terjadi pada saat sakit ditandai dengan ketidakmampuan untuk menekan produksi glukosa hepar. $^{13}$

\section{Kesimpulan}

Berdasarkan hasil penelitian terhadap kasus kejang demam di bangsal anak RSUP Dr. M. Djamil Padang periode Januari 2010 - Desember 2012, didapatkan kesimpulan sebagai berikut :

1. Jenis kejang demam terbanyak yang terjadi adalah kejang demam kompleks

2. Kasus kejang demam sebagian besar merupakan episode kejang pertama dengan perbandingan kejang pertama dengan kejang ulangan sebesar $3,3: 1$.

3. Kelompok usia terbanyak penderita kejang demam adalah $\geq 6$ bulan $-<1$ tahun dan $\geq 1$ tahun - <2 tahun

4. Kejang demam lebih sering terjadi pada laki-laki dengan perbandingan laki-laki dan perempuan sebesar $1,4: 1$

5. Sebagian besar kasus kejang demam dengan penurunan nilai natrium serum

6. Sebagian besar kasus kejang demam memiliki nilai kalium serum yang normal

7. Kasus kejang demam dengan penurunan nilai kalsium serum ditemukan sebesar $63,3 \%$

8. Kasus kejang demam dengan peningkatan nilai gula darah sewaktu ditemukan sebesar $57,8 \%$ 


\section{Daftar Pustaka}

1. Friedman, Marla J., Ghazala Q. Sharieff, 2006. Seizures in Children. Pediatric Clinics of North America. 53: 257- 277

2. Bahtera, Tjipta., Susilo Wibowo, AG Soemantri Hardjojuwono, 2009. Faktor Genetik Sebagai Risiko Kejang Demam Berulang. Sari Pediatri. 10: 378-384

3. Shinnar, Shlomo., dan Christine O'Dell. 2004. Febrile Seizures. Pediatric Annals, 33, 6: 394-401

4. Rowland, Lewis P. dan Timothy A. Pedley. 2010. Merritt's Neurology Twelfth Edition. Lippincott Williams \& Wilkins: Pg. 949-950

5. Soetomenggolo, Taslim S., 2000. Buku Ajar Neurologi Anak Cetakan Ke-2. Jakarta: Bagian IImu Kesehatan Anak Fakultas Kedokteran Universitas Indonesia: hal 244-251

6. Ivanny, Putri Sari., 2007. Gambaran Faktor-faktor Risiko yang Menyebabkan Terjadinya Kejang Demam Pertama Kali pada Anak di Bangsal Anak RSUP Dr. M. Djamil Padang Periode Januari 2005-Desember 2006. Skripsi. Universitas Andalas, Padang: hal. 13-35

7. Khanis, Abdul., 2010. Defisiensi Besi dengan Parameter sTfR sebagai Faktor Risiko Bangkitan Kejang Demam. Tesis, Universitas Diponegoro, Semarang

8. Millar, James S., 2006. Evaluation and Treatment of the Child with Febrile Seizure. American Family Physician. 73: 1761-4

9. Nickavar, Azar., Hosein Hasanpour, dan Kambiz Sotoudeh, 2009. Validity of Serum Sodium and Calcium Screening in Children with Febrile Convulsion. Acta Medica Iranica. 47 (3): 229-231

10. Zeng-quan, Yuan., Jiang Wei, 2009. Clinical Significance of Changes of Blood Sodium, Potassium, Calcium and Glucose in Children with Febrile Convulsion. [Abstract]. Journal of Bengbu Medical College. 05

11. Ganong, W. F., 2008. Buku Ajar Fisiologi Kedokteran Edisi 22. Alih bahasa Brahm U. Pendit. EGC: 41-72

12. Akbayram, Cemek $M$, Büyükben $A$, Aymelek $F$, Karaman S, Yilmaz F, dkk, 2012. Major and Minor Bio-element Status in Children with Febrile Seizure. [Abstrac]. Bratisl Lek Listy. 113(7): 421-3

13. Dungan, Kathleen M., Susan S Braithwaite, JeanCharles Preiser, 2009. Stress Hyperglycaemia Lancet. 373: 1798-807 